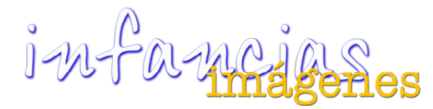

http://revistas.udistrital.edu.co/ojs/index.php/infancias

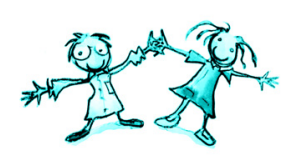

SEPARATA ESPECiAL

\title{
$\checkmark$ Coloquio de Infancia Las palabras, las niñas y los niños: poemas y relatos, canciones y rondas, dibujos y libros
}

\author{
Karina Claudia Bothert ${ }^{1}$
}

En el segundo semestre del presente año, se llevó a cabo el $\mathrm{V}$ Coloquio de Infancia, organizado por el grupo de investigación Lenguaje, Discurso y Saberes; la Cátedra Unesco en Desarrollo del Niño; la Maestría en Infancia y Cultura, y la Especialización en Infancia, Cultura y Desarrollo de la Universidad Distrital Francisco José de Caldas.

Este espacio académico buscó generar encuentros diferentes al del aula de clases, donde se hicieran presentes el diálogo y la reflexión sobre aspectos relevantes para el proceso formativo.

El tema que nos reunió en esta ocasión fue "Las palabras, las niñas y los niños: poemas y relatos, canciones y rondas, dibujos y libros".

El interés y el estudio sobre las palabras no es nuevo; por el contrario, es de vieja data, tanto en lo referente al desarrollo filogenético como ontogenético. Por ejemplo, en el grupo de investigación Lenguaje, Discurso y Saberes, en sus casi 20 años de existencia, cada uno de los trabajos que sobre lenguaje, narrativas y relatos realiza, se convierte en una disculpa para acercarnos al mundo de las palabras con las que, como adultos guía, tutores, educadores, pedagogos, psicólogos, padres, facilitamos o no los procesos tanto de humanización del niño y de la niña, como el aún más complejo devenir como sujeto.

Sabemos del peso, del rol y de la importancia que tienen las palabras; es a través de y por ellas que el ser humano se ha distanciado de los otros animales. Ellas están allí dispuestas, antes de nuestra llegada al mundo, marcando la forma como somos recibidos y acunados para, finalmente, ser la plataforma a partir de la cual: interpretamos lo que nos rodea, damos crédito o culpamos a nuestros semejantes, y negociamos nuestras relaciones con ellos.

Muchas preguntas con respecto a las palabras en la vida del ser humano en general, y en el niño y la niña en particular nos llegan: por ejemplo, ¿cuáles son las palabras prohibidas?; ¿cuáles son aquellas que nos gustaría que fueran borradas de la lengua, del diccionario?; y ipor qué las borraríamos?, quizás porque han hecho demasiado daño, quizás porque han servido más para destruir que para construir...

Hoy nuestra apuesta es pensar en aquellas palabras que han estado al servicio del bienestar humano, al servicio de la alegría de nuestros niños; palabras que calman; remedian; acompañan; muestran caminos; acogen; contienen; explican; invitan al amor, al perdón; que dan ganas y convidan a engancharse al mundo y a la cultura.

Dos cosas quisiera acotar al tema que nos convoca con respecto a las palabras y los productos discursivos de los niños y las niñas: ¿qué es un texto?, y ¿quién es un buen receptor de ese texto? A partir de lo señalado por Fréderic Françoise ${ }^{2}$ y de los diversos corpus de textos infantiles, se puede constatar que un texto es todo discurso (oral o

\footnotetext{
1 Magíster en Psicología del Niño y del Adolescente de I'Université René Descartes Paris V. Docente investigadora e integrante del grupo de investigación Lenguaje, Discurso y Saberes de la Universidad Distrital Francisco José de Caldas. Editora de la revista Infancias Imágenes. Correo electrónico: catapizrojo@yahoo.com

2 Filósofo y lingüista. Profesor en el área de ciencias del lenguaje en la Universidad René Descartes París V.
} 
escrito) que se encuentra en situación de percepción terciaria, fuera de las condiciones primarias de su enunciación. Un texto existe en efecto y actúa independientemente de la forma en que ha sido producido.

Antes que hablar de tipos de textos cuyo inventario estaría cerrado, sería más interesante encontrar afinidades entre: el objeto del cual se habla, la manera de hablar y a quien se habla. Así, un texto nos ofrece una cierta figura del mundo al cual nos reenvía, una cierta organización de los enunciados para referirnos a ese mundo y un cierto tipo de interlocución ante un interlocutor percibido de manera particular (familiar o lejano, sabio o ignorante, a quien se ama o se teme, al que hay que convencer o no...).

Es un buen receptor aquel capaz de una alteridad en relación con los otros y con sí mismo, es un buen receptor aquella persona capaz de poner una distancia cultural y al mismo tiempo capaz de una empatía que le permita seguir siendo sí mismo, sin Ilevar todo de su lado; la problemática de este tipo de recepción se une a aquella de la identidad, en el sentido de poder seguir siendo en relación con la percepción del otro. Esto quiere decir que el niño debe ser considerado como una persona otra, entera (y no como un modelo reducido del adulto) que posee una cultura diferente a la del adulto.
Evidentemente y contrariamente a otros casos de alteridad, todo adulto ha sido un niño.

Con respecto a la segunda pregunta, ¿qué hace que se pueda ser un buen receptor de textos?, nos posicionamos más del lado de la cultura. En consecuencia, el primer obstáculo cultural que dificulta una adecuada recepción de los textos infantiles es el adultocentrismo espontáneo de los adultos, quienes solo vemos en las producciones infantiles las faltas en relación a nuestras propias producciones, tomadas como modelos. Esto hace que se deje de lado, primero, la especificidad de los textos infantiles $y$, segundo, su gran poder de invención. Viciados por esta dinámica, y ciegos por dirigir el inventario de errores y de faltas, nos privamos de ver la fuerza de los procesos de aprendizaje de los niños y las niñas, sabiendo que hablando y escribiendo a su manera todo niño aprende a hablar y a escribir. Sus producciones no son simplistas, ni extraordinarias; ellas son, por naturaleza, dignas del más grande interés, humana y científicamente hablando.

Con este preámbulo presentamos en esta separata, tres de las ponencias que fueron parte del Coloquio, con el fin de socializar las reflexiones que desde la lingüística, la literatura y la creación literaria se han generado alrededor de las palabras, las niñas y los niños. 